\title{
Comparative study of the chemical composition and biological activities of the essential oils of Senecio gallicus from Tunisia.
}

Mohamed Mihoubi ${ }^{1 *}$, Wafa Mihoubi ${ }^{2}$, Ali Gargouri ${ }^{2}$ and Raoudha Jarraya ${ }^{1}$

${ }^{1}$ Laboratoire de Chimie des Substances Naturelles, UR11-ES74, Faculté des Sciences de Sfax, BP 1171, 3000 Sfax, Tunisia.

${ }^{2}$ Laboratoire de Valorisation de la Biomasse et de la Production des Proteines chez les Eucaryotes, Centre national de Biotechnologie de Sfax (CBS), 3000 Sfax,Tunisia.

E-mail addresses: *Mohamed.Mihoubi@hotmail.fr (corresponding author), Fafani.Mihoubi@yahoo.fr, Faouzi.gargouri@cbs.rnrt.tn, Raoudhajarraya@yahoo.fr

Tel: (00216) 21625508

\begin{abstract}
The essential oils of flowers and remaining parts of the plant Senecio gallicus (Asteraceae), growing wild in Sfax (Tunisia), were obtained by hydrodistillation over a period of two years (2012 and 2013). Their analysis by Gas ChromatographyMass Spectrometry (GC-MS), led to a total number of 36 components, belonging to different classes of chemical compounds. Oils compositions were characterized by the abundance of monoterpenes hydrocarbons, the major compounds present in flowers for the two years of study were respectively the sabinene $(49.45 \%$ and $28.86 \%)$, the $\alpha$ pinene $(9.67 \%$ and $9.1 \%)$, and the $\beta$-myrcene $(9.88 \%$ and $10.97 \%)$. These compounds were also dominant in the essential oils of the plant without flowers where they represent $(65.34 \%$ and $55 \%)$ for the sabinene, $(4.14 \%$ and $7.3 \%)$ for $\alpha$-pinene, and $(6.86 \%$ and $0 \%)$ for $\beta$-myrcene. Obtained essential oils were tested for many biological activities and showed a moderate effect against the fungus Trichoderma reesei and bacteria such as Bacillus sp and Staphylococcus aureus. This study of the Senecio gallicus essential oils represents the first one in Tunisia.
\end{abstract}

\section{Keywords}

Senecio gallicus; Essential Oils; chemical composition; Sabinene; antifungal activity.

\section{Academic Discipline And Sub-Disciplines}

Sciences; Chemistry; Biochemistry.

\section{SUBJECT CLASSIFICATION}

Chemistry of fragrances and essential oils.

\section{TYPE (METHOD/APPROACH)}

Comparaison of obtained experimental researches.

\section{Council for Innovative Research}

Peer Review Research Publishing System

Journal: Journal of Advances in Chemistry

\author{
Vol. 10, No. 8 \\ editorjaconline@gmail.com
}




\section{INTRODUCTION}

Senecio gallicus is a plant that belongs to the Asteraceae family [1,2]. The genus Senecio comprises about 1300 species [3]. Alkaloids and sesquiterpenes are the major components in this genus [4-6], especially pyrrolizidine alkaloids [7]. In folk medicine, Senecio species have been used for the treatment of wounds as well as anti-inflammatory and vasodilator preparations [8-10]. It was also reported that Senecio graveolens (Compositae) can be used for the treatment of mountain sickness [11]. These authors have isolated from molecules endowed of a strong antihypertensive activity through inhibition of the angio-tensin converting enzyme (ACE) [11]. Few reports about essential oil contents of members of the genus Senecioneae have been reported [12-18].

In Tunisia, Senecio gallicus species account for $5 \%$ of all Asteraceae localized in the south of the country [12], growing up during the period of spring when nutritional conditions are favorable [19]. Generally, this plant is found in altitudes between 15 and 1500 meters; its life cycle is very short and usually does not exceed few weeks [12]. Several previous works showed the richness of this plant in flavonoids, alkaloids [20], terpenes [21] and minerals [22]. In Tunisian traditional medicine, Senecio gallicus has been used to regulate blood circulation and as a uterine sedative [23,24]. Akrout et al studied eight annual species growing wild in the southern of Tunisia (Diplotaxis simplex, Chrysanthemum coronarium, Matthiola longipetela, Erodium glaucophyllum, Reseda alba, Diplotaxis harra, Senecio gallicus and Papaver rhoeas) by evaluating their mineral contents and phytochemical screening [24]. They mentioned that Senecio gallicus and Chrysanthemum coronarium were the only species that contained essential oils but they didn't determine their exact composition and the nature of essential oils [24].

The richness of $S$. gallicus in mineral, oils and other secondary metabolites stimulated our interest to study the chemical composition of its essential oils, for the different compartments of the plant (flowers, and remaining parts) and to evaluate some of their biological activities.

\section{EXPERIMENTAL PART}

\section{Plant Material}

Senecio gallicus, in full bloom, were collected during the spring (month of March) over the two years 2012 and 2013 at the same place in the city of Sfax (Tunisia) (Table 1.). Voucher specimens (LCSN 116) were authenticated by Pr. Mohamed Chaieb and have been deposited in the "Laboratoire de Chimie des Substances Naturelles" of the Faculty of Sciences of Sfax. Fresh aerial parts were cut in small pieces and subjected to hydrodistillation for 3 hours. The volatiles were extracted using diethyl ether as solvent; the organic phases were subsequently dried over anhydrous sodium sulphate and then evaporated under vacuum. Obtained yellowish essential oils, with a pleasant scent, were stored under $\mathrm{N}_{2}$ atmosphere in amber vials at $4{ }^{\circ} \mathrm{C}$ until they were analyzed.

Table 1. Collection data and oils yields of investigated Senecio gallicus.

\begin{tabular}{|c|c|c|c|c|c|}
\hline \multirow{2}{*}{ Species } & $\begin{array}{c}\text { Voucher } \\
\text { number }\end{array}$ & $\begin{array}{c}\text { Collection } \\
\text { Period }\end{array}$ & \multirow{2}{*}{ Region } & \multicolumn{2}{|c|}{$\begin{array}{c}\text { Essential oil yield } \\
\text { (\% v/ weight) }\end{array}$} \\
\cline { 5 - 6 } & LCSN 116 & Mars 2012 & \multirow{2}{*}{$\begin{array}{c}\text { Tunis Road km 6, } \\
\text { Sfax (Tunisia) }\end{array}$} & 0,14 & 0,037 \\
\cline { 2 - 3 } \cline { 5 - 6 } & LCSN 116 & Mars 2013 & & 0,14 & 0,038 \\
\hline
\end{tabular}

\section{Microorganism and Media}

The test organisms used in this study were Staphylococcus sp, Bacillus sp, Trichoderma reesei and Aspergillus niger obtained from the Microbial Type Culture Collection, CBS, Sfax (Tunisia).

\section{Essential oils isolation}

The fresh plant was divided into two parts, flowers and the remaining part of the plant without flowers (named here plant w/o flowers). Extraction of the essential oils from each part was performed using the method of steam distillation. Each organ was hydrodistillated alone. $1082 \mathrm{~g}$ and $700 \mathrm{~g}$ of fresh flowers collected over the period of two years have been contacted with water in a conventional hydrodistillator for a period of 3 hours. After distillation, the oil was collected and dried with anhydrous sodium sulfate $\mathrm{Na2SO}$, and was kept away from light and heat at a temperature of $4{ }^{\circ} \mathrm{C}$ until analyzed. The same procedure was made with $1110 \mathrm{~g}$ and $700 \mathrm{~g}$ of plant devoid of flowers.

\section{Analysis of the essential oils}

Analyzes of the essential oils were performed using an Agilent 6890 gas chromatograph equipped with a fused silica capillary column type HP-5MS (5\% phenyl-methyl-siloxane, $30 \mathrm{~m} \times 0.25 \mathrm{~mm}$ film, thickness 0.25 microns, Agilent Technologies, USA). The temperature of the interface and of the injector was operated at $280^{\circ} \mathrm{C}$ and $250{ }^{\circ} \mathrm{C}$, respectively. 
The oven temperature arose from $35^{\circ} \mathrm{C}$ to $325^{\circ} \mathrm{C}$ with a heating rate of $5{ }^{\circ} \mathrm{C} / \mathrm{min}$. Helium was used as the cooling gas at a rate of $1 \mathrm{~mL} / \mathrm{min}$.

The essential oils were identified by determining their Kovats indices [25], calculated using the retention times of injected alkane series with a number of carbon atoms ranging from $\mathrm{C}_{8}$ to $\mathrm{C}_{28}$ with the same chromatographic conditions, in addition to the Kovats indices obtained from the literature, we have considered in this study only the compounds that possess similar Mass spectra to those obtained from the WILEY $7 \mathrm{n}$.I library with a quality greater than $90 \%$. The percentage of the identified compounds is deduced from their peak areas.

\section{Biological Screening}

The microbial inoculums were uniformly spread using sterile spreader on a sterile Petri contain microbial media agar (LB (Luria-Bertani) for bacteria and PDA (potato dextrose agar) for fungi). $100 \mu \mathrm{L}$ of each Essential oil were loaded in wells dug in agar plates ( $7 \mathrm{~mm}$ diameter holes). at concentrations of 15 and $10 \mathrm{mg} / \mathrm{mL}$ in DMSO. Products were added to each well. The bacterial systems were incubated for $24 \mathrm{~h}$ at $37^{\circ} \mathrm{C}$ and fungal system was incubated for $72 \mathrm{~h}$ at $30^{\circ} \mathrm{C}$, under aerobic conditions. After incubation, confluent microbial (bacteria or fungi) growth was observed. Inhibition of the microbial growth was measured in $\mathrm{mm}$.

The antibacterial and antifungal activities of the essential oils samples in terms of minimum inhibitory concentrations (MIC) and diameters of inhibition zones are reported in the table 4.

\section{RESULTS AND DISCUSSION}

\section{Chemical composition of the essential oils}

The chemical composition of essential oils extracted from Senecio gallicus species and identified by GC-MS is shown in Table 2. The quantitative and qualitative analyzes allowed us to identify a total number of 36 components belonging to different classes of chemical compounds. For those collected in the year 2012, 22 volatile compounds were found, among them 18 components were common to both compartments (flowers and plant w/o flowers). We can cite: $\alpha$-Thujene, $\alpha$ Pinene, Sabinene, $\beta$-Myrcene, 1-Phellandrene, $\alpha$-Terpinene, Orthocymene, $\beta$-Phellandrene, $\gamma$-Terpinene, $\alpha$-Terpinolene, 4-Terpineol, Trans Caryophylene, $\alpha$-Humulene and Germacrene D. Concerning the year 2013 collect, 32 compounds were identified among them only 4 components were common to both compartments (which are $\alpha$-Pinene, Sabinene, 4 Terpineol and Germacrene D). This would be caused by the decrease in the number of components in the plant w/o flowers essential oil on the 2013 campaign. It is also apparent that the extraction yield of essential oils was more important in the second year than in the first one.

All these significant differences in the chemical composition of these different oils led us to conclude that the essential oils composition seems to be influenced by the geographical locations, seasons, climatological conditions and a possible existence of chemotypes or ecotypes.

Table 2. Chemical compositions (\%) of Senecio gallicus essential oils.

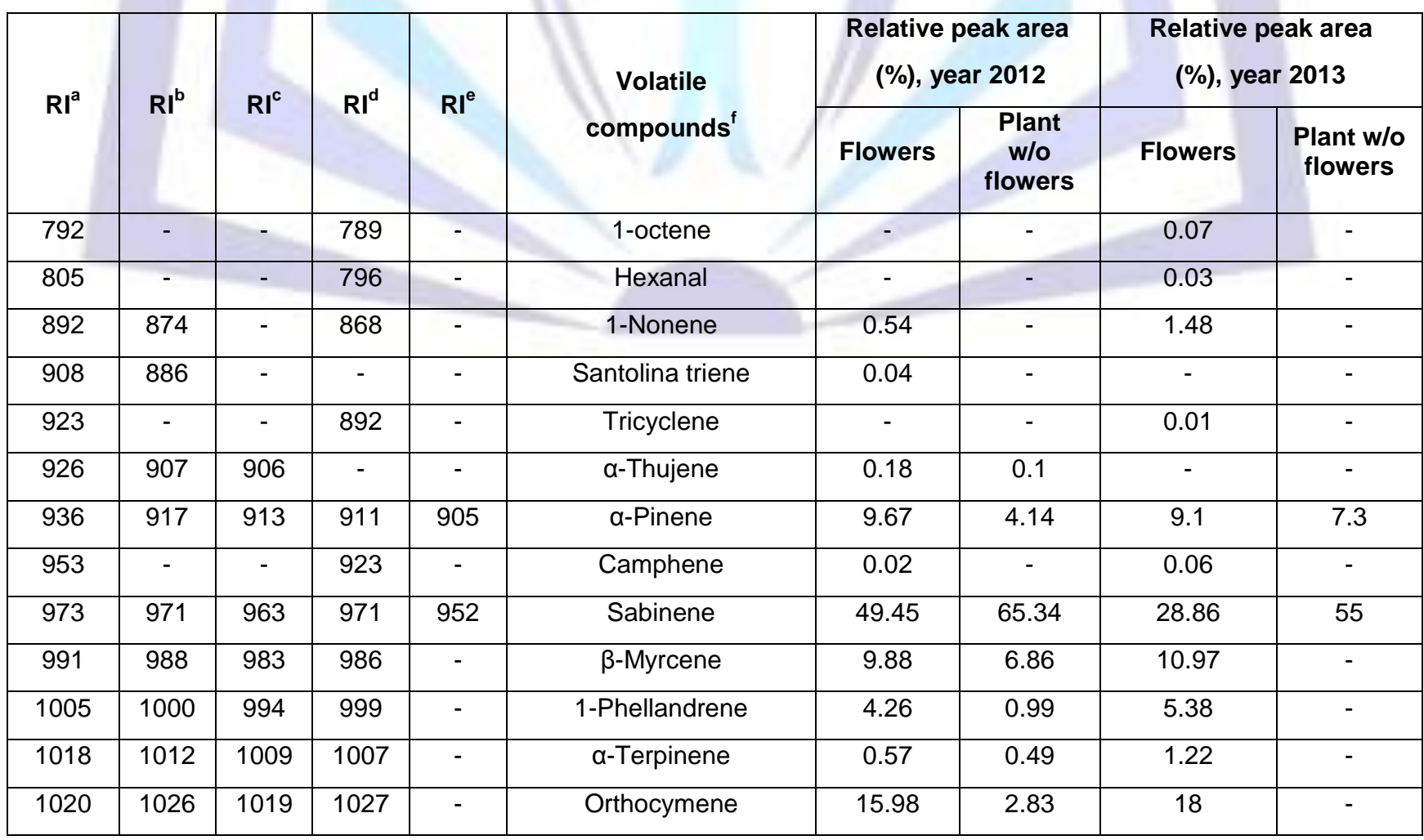




\begin{tabular}{|c|c|c|c|c|c|c|c|c|c|}
\hline 1053 & 1029 & 1024 & 1030 & - & $\beta$-Phellandrene & 3.39 & 4.27 & 2.45 & - \\
\hline 1040 & - & - & 1033 & - & Cis Ocimene & - & - & 0.19 & - \\
\hline 1059 & 1036 & 1058 & 1056 & - & $\mathrm{Y}$-Terpinene & 0.79 & 0.82 & 2 & - \\
\hline 1043 & - & 1047 & 1043 & - & $\beta$-Ocimene & - & 0.45 & 0.57 & - \\
\hline 1101 & - & 1058 & 1064 & - & Cis Sabinene & - & 0.82 & 0.51 & - \\
\hline 1084 & 1094 & 1089 & 1089 & - & $\alpha$-Terpinolene & 1.15 & 3.06 & 2.99 & - \\
\hline 1068 & - & 1105 & - & - & Isoterpinolene & - & 0.24 & - & - \\
\hline 1198 & - & - & 1099 & - & Terpineol & - & - & 0.54 & - \\
\hline 1207 & 1153 & - & 1148 & - & 1-Terpineol & 0.02 & - & 0.55 & - \\
\hline 1179 & 1196 & 1195 & 1195 & 1196 & Terpinene-4-ol & 2.3 & 3.02 & 7.27 & 21.36 \\
\hline 1288 & - & - & 1306 & - & Lavandulyl Acetate & - & - & 0.21 & - \\
\hline 1380 & - & - & 1344 & - & Decanoic Acid & - & - & 0.29 & - \\
\hline 1393 & - & - & 1369 & - & $\beta$-Elmene & - & - & 0.07 & - \\
\hline 1410 & 1405 & 1405 & 1396 & - & Trans Caryophyllene & 0.08 & 0.32 & 0.5 & - \\
\hline 1485 & - & - & 1449 & - & $\beta$-Selinene & - & - & 0.03 & - \\
\hline 1459 & 1450 & 1404 & 1437 & - & $\alpha$-Humulene & 0.03 & 0.17 & 0.14 & - \\
\hline 1499 & 1484 & 1484 & - & 1473 & Germacrene D & 0.2 & 0.31 & - & 5.43 \\
\hline 1389 & - & - & 1473 & - & $\beta$-Cubenene & - & - & 0.03 & - \\
\hline 1494 & 1503 & - & 1490 & - & Bicyclogermacrene & 0.06 & - & 0.84 & - \\
\hline 1519 & - & - & 1523 & - & $\delta$-Cadinene & - & - & 0.32 & - \\
\hline 1640 & - & - & 1690 & - & Tau murolol & - & 0.11 & - & - \\
\hline 1605 & - & - & 1624 & 1624 & Oplopenone & - & - & 0.11 & 0.35 \\
\hline 1658 & - & - & 1677 & - & $\alpha$-Cadinol & - & - & 3.27 & - \\
\hline \multicolumn{5}{|c|}{ Total identified } & 37 & 98.59 & 94.02 & 98.06 & 89.44 \\
\hline \multicolumn{5}{|c|}{ Monoterpenes } & & \multicolumn{2}{|c|}{21} & & \\
\hline \multicolumn{5}{|c|}{ Hydrocarbons } & & \multicolumn{2}{|c|}{17} & & \\
\hline \multicolumn{5}{|c|}{ Oxygenated } & & \multicolumn{2}{|c|}{4} & & \\
\hline \multicolumn{5}{|c|}{ Sesquiterpenes } & & \multicolumn{2}{|c|}{11} & & \\
\hline \multicolumn{5}{|c|}{ Hydrocarbons } & & \multicolumn{2}{|c|}{8} & & \\
\hline \multicolumn{5}{|c|}{ Oxygenated } & & \multicolumn{2}{|c|}{3} & & \\
\hline \multicolumn{5}{|c|}{ Others } & & \multicolumn{2}{|c|}{5} & & \\
\hline
\end{tabular}

${ }^{\text {a }} \mathrm{RI}$ : Retention indices on HP-5 MS column relative to C9-C28 n-alkanes.

${ }^{b} \mathrm{RI}$ : Retention indices of volatile compounds of flowers, analyzed on 2012.

${ }^{c}$ RI: Retention indices of volatile compounds of the plant devoid of its flowers, analyzed on 2012.

${ }^{\mathrm{d}} \mathrm{RI}$ : Retention indices of volatile compounds of flowers, analyzed on 2013.

${ }^{\text {e }} \mathrm{RI}$ : Retention indices of volatile compounds of the plant devoid of its flowers, analyzed on 2013.

${ }^{f}$ Volatile compounds: constituents listed in order of elution from a HP-5 MS column.

The essential oils composition of the different organs of Senecio gallicus was quite distinct as shown in table 2 and also figures 1, 2 and 3. The volatile oils extracted from different parts of Senecio gallicus species varied not only quantitatively but also qualitatively. It is easily distinguishable from the first sight, that Sabinene was the most abundant component in all plant organs during the two years. The plant w/o flowers posses the major concentration of Sabinene (65.34\%) for the year 2012. This value decreased to $55 \%$ on the second year. This compound was also present in the plant w/o flowers 
with a concentration ranging from $49.45 \%$ to $28.86 \%$ respectively to the two years. Thus, in Senecio gallicus species, the volatile oils extracted from plant w/o flowers had a higher concentration of Sabinene. For the Iranian essential oil already reported [26], the concentration of Sabinene was 7.2\%. All these results could confirm the estimations of Lawrence [27], who had demonstrated that the concentration of Sabinene in essential oils ranges from $0.4 \%$ to $64.5 \%$.

Regarding the variation on the chemical composition of obtained volatile oils, we can conclude that the percentage and the nature of components depend on the analyzed organ. This variation can also be seen in the same organ, in two different periods of time; like the case of flowers when some minor components appeared on the second year, such as (1-Octene $0.07 \%$, Hexanal $0.03 \%$, Tricyclene $0.01 \%$, Camphene $0.06 \%$, Cis Ocimene $0.19 \%$, Terpineol $0.54 \%$, Lavandulyl acetate $0.21 \%$, Decanoic acide $0.29 \%$, $\beta$-Elmene $0.07 \%$, $\beta$-Selinene $0.03 \%$, $\beta$-Cubenene $0.03 \%$, $\Gamma$-Cadinene $0.32 \%$, $\alpha$-Cadinol $3.27 \%)$.

Concerning the plant w/o flowers, some of the components that were present the first year like ( $\alpha$-Thujene $0.1 \%, \beta$ Myrcene $6.86 \%$, 1-Phellandrene $0.99 \%$, $\alpha$-Terpinene $0.49 \%$, Orthocymene $2.83 \%$, $\beta$-Phellandrene $4.27 \%, \gamma$-Terpinene $0.82 \%$, $\beta$-Ocimene $0.45 \%$, Cis Sabinene $0.82 \%$, $\alpha$-Terpinolene $3.06 \%$, Isoterpinolene $0.24 \%$, Trans Caryophylene $0.32 \%$, a-Humulene $0.17 \%$, Tau murolol $0.11 \%$ ) were absent in the second year. The only present compounds, in the second year were ( $\alpha$-Pinene 7.3\%, Sabinene 55\%, Terpinene-4-ol 21.36\%, Germacrene D 5.43\% and Oplopenone 0.35\%). There are only 4 common compounds shared between the two compartments we mention: ( $\alpha$-Pinene, Sabinene, Terpinene-4-ol and Germacrene D).

The chemical composition of flowers and plant w/o flowers obtained in the first year (figure 1) shared some components, with some relative difference in the concentrations. The common compounds are: ( $\alpha$-Thujene, $\alpha-P i n e n e$, Sabinene, $\beta-$ Myrcene, 1-Phellandrene, $\alpha$-Terpinene, Orthocymene, $\beta$-Phellandrene, $\gamma$-Terpinene, $\alpha$-Terpinolene, Terpinene-4-ol, Trans Caryophylene, $\alpha$-Humulene and Germacrene D). The difference between these compartments consists of the minor compounds that are present only in flowers. We can respectively mention 1 -Nonene $0.54 \%$, santolinatriene $0.04 \%$, 1 Terpineol $0.02 \%$, Bicyclogermacrene $0.06 \%$. For those which are present only in the plant w/o flowers we can name $\beta$ Ocimene $0.45 \%$, Cis Sabinene $0.82 \%$, Isoterpinolene $0.24 \%$ and Tau murolol $0.11 \%$.

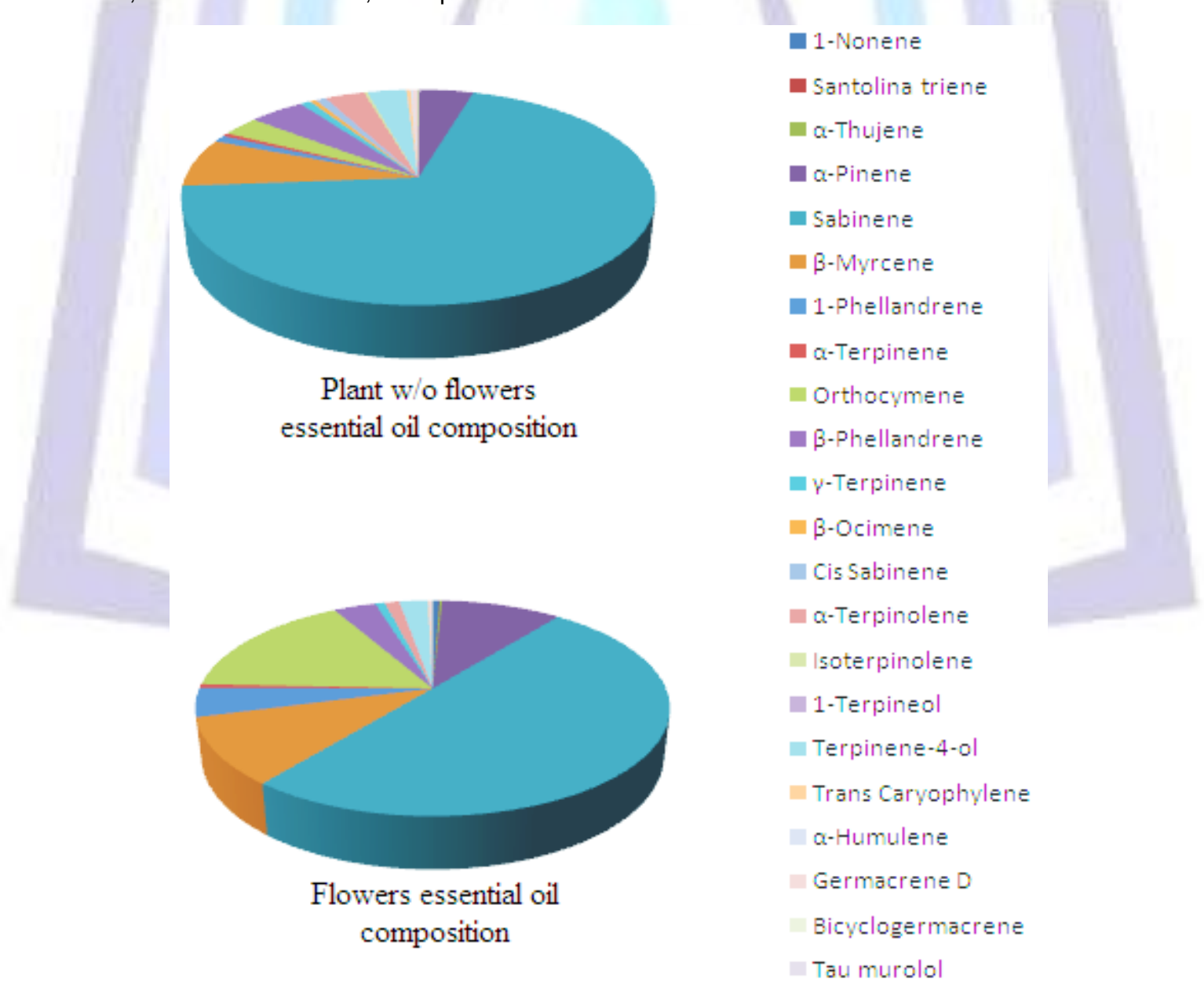

Figure 1. Essential oils composition of Senecio gallicus harvested in 2012.

For the second year, the plant w/o flowers showed a low countenance of terpenes and possessed only ( $\alpha$-Pinene $7.3 \%$, Sabinene 55\%, Terpinene-4-ol 21.36\%, Germacrene D 5.43\% and Oplopenone $0.35 \%$ ). The Germacrene D was absent in the flowers, these last showed a total number of 27 specific different volatiles represented by: (1-Octene $0.07 \%$, Hexanal $0.03 \%$, 1-Nonene $1.48 \%$, Tricyclene $0.01 \%$, $\alpha$-Pinene $9.1 \%$, Camphene $0.06 \%$, Sabinene $28.86 \%$, $\beta$-Myrcene $10.97 \%, 1$ - 
Phellandrene $5.38 \%$, $\alpha$-Terpinene $1.22 \%$, Orthocymene $18 \%, \beta$-Phellandrene $2.45 \%$, Cis Ocimene $0.19 \%$, $\gamma$-Terpinene $2 \%$, $\beta$-Ocimene $0.57 \%$, Cis Sabinene $0.51 \%$, $\alpha$-Terpinolene $2.99 \%$, Terpineol $0.54 \%, 1-T e r p i n e o l ~ 0.55 \%$, Terpinene-4-ol $7.27 \%$, Lavandulyl Acetate 0.21\%, Decanoic Acid 0.29\%, $\beta$-Elmene 0.07, Trans Caryophylene 0.5\%, $\beta$-Selinene $0.03 \%$, $\alpha$ Humulene $0.14 \%, \beta$-Cubenene $0.03 \%$, Bicyclogermacren $0.84 \%$, $\delta$-Cadinene $0.32 \%$, Oplopenone $0.11 \%$ and $\alpha$-Cadinol $3.27 \%$ ). Essential oils obtained from flowers on 2013, acquired a large number of components compared by those obtained on the first year.
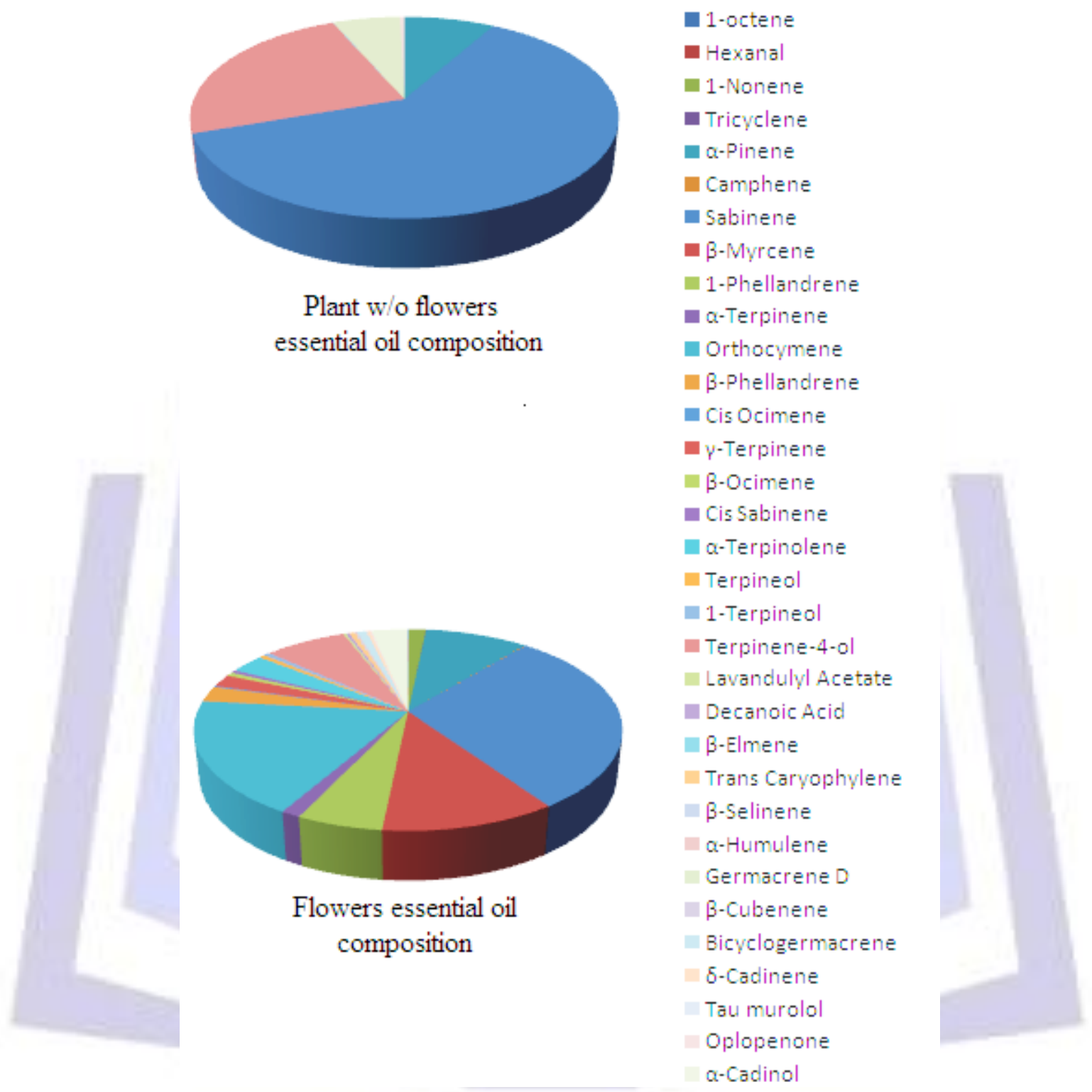

Figure 2. Essential oils composition of Senecio gallicus harvested in 2013.

We compared our results with the previously published ones by Mohammadhosseini et al for the same plant Senecio gallicus from Iran [26]. Some similarity and a large difference are observed between the compositions of all studied samples (our two years samples for the two compartments and the Iranian one for the whole plant). Oils reported in this current work were characterized by the dominance of Sabinene which is present as major compound in the two compartments during the two years with concentration varying between $49.45 \%$ and $28.86 \%$ in flowers, and $65.34 \%-55 \%$ in the plant w/o flowers. The Iranian work [26] which studied oils obtained from of the whole plant (without separating its organs) has shown that $\beta$-Phellandrene is the most abundant component at a concentration of $12.2 \%$, along with some other volatile compounds that we have already found in our samples ( $\alpha$-Pinene, Sabinene, Terpinolene, Terpinen-4-ol, $\alpha$ Humulene, Germacrene-D, ס-Cadinene).

We mention here that $\alpha$-Pinene that is common to all the samples, posses a relative stable concentration especially in both flowers and Iranian essential oils. This concentration decreases in the oils of Plant w/o flowers. 


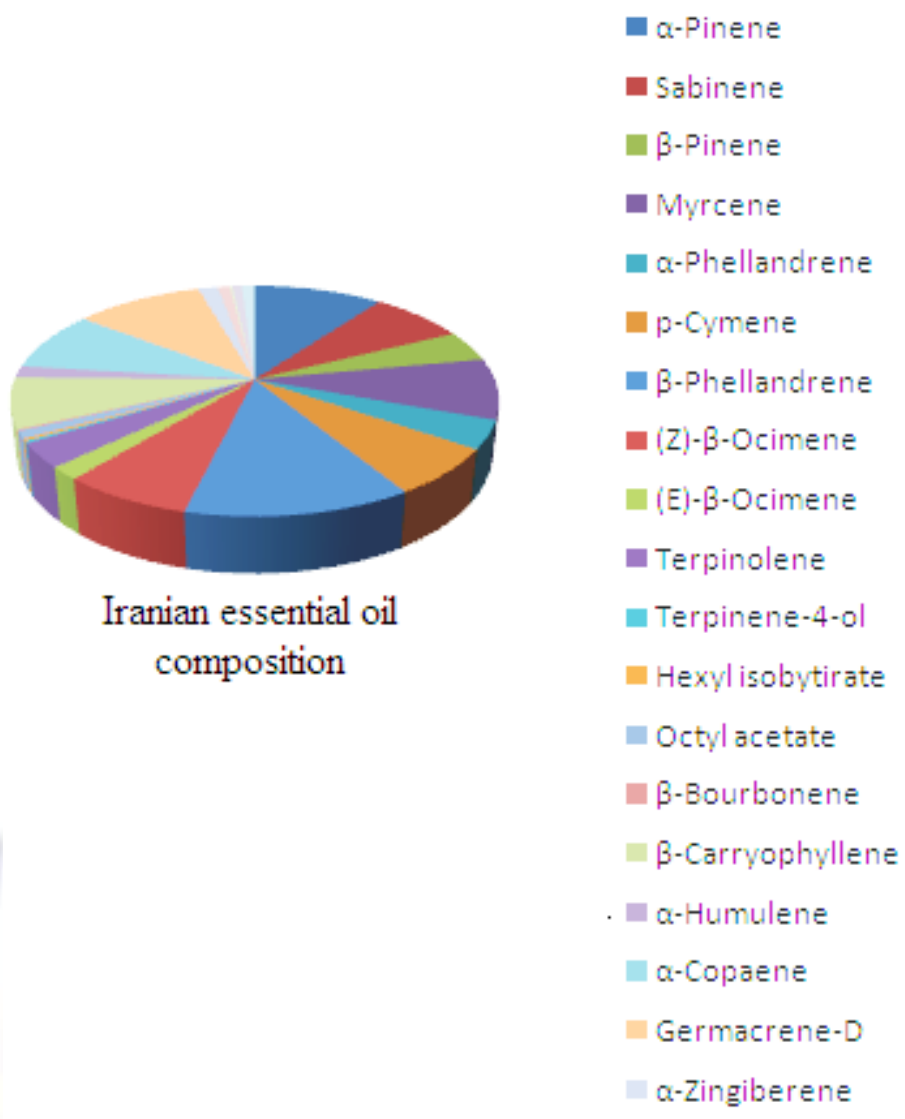

Figure 3. Composition of Senecio gallicus essential oils from Iran [26].

Common compounds and concentrations of our oils and those already reported are listed in table 3.

Table 3. Common compounds between different essential oils.

\begin{tabular}{|c|c|c|c|c|c|}
\hline \multirow{2}{*}{$\begin{array}{l}\text { Common volatile } \\
\text { compounds }\end{array}$} & \multicolumn{2}{|c|}{$\begin{array}{c}\text { Relative peak area(\%), } \\
\text { year } 2012\end{array}$} & \multicolumn{2}{|c|}{$\begin{array}{c}\text { Relative peak area(\%), } \\
\text { year } 2013\end{array}$} & \multirow{2}{*}{$\begin{array}{c}\text { Relative peak area } \\
\text { for already reported } \\
\text { essential oils }\end{array}$} \\
\hline & Flowers & $\begin{array}{l}\text { Plant w/o } \\
\text { flowers }\end{array}$ & Flowers & $\begin{array}{l}\text { Plant w/o } \\
\text { flowers }\end{array}$ & \\
\hline$\alpha$-Pinene & 9.67 & 4.14 & 9.1 & 7.3 & 9.8 \\
\hline Sabinene & 49.45 & 65.34 & 28.86 & 55 & 7.2 \\
\hline R-Ocimene & & 015 & 0 & & (Z)- $\beta$-Ocimene: 7.0 \\
\hline & & & & & 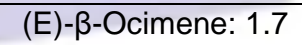 \\
\hline Terpinene-4-ol & 2.3 & 3.02 & 7.27 & 21.36 & 0.3 \\
\hline$\alpha$-Humulene & 0.03 & 0.17 & 0.14 & - & 1.6 \\
\hline Germacrene-D & 0.2 & 0.31 & - & 5.43 & 9.8 \\
\hline$\delta$-Cadinene & - & - & 0.32 & - & 0.2 \\
\hline
\end{tabular}

\section{Biological activities of the essential oils}

Total extracts of essential oils from Senecio gallicus were assayed for their biological activities such as the antioxidant activity that was evaluated by the DPPH method.

The essential oils were not able to capture free radicals and the antioxidant activity assays were very low. This result can be related to the low reactivity of the highly concentrated compound which is Sabinene, toward hydroxyl groups. This reaction is confirmed by Atkinson, Ashmann et al [28]. Some other few studies [28-30], expected that Sabinene can be oxidized by ozone or hydroxyl groups to give a new compound containing 9 carbons named sabinacetone; but there is no experimental test that verified this theory. 
We have also tested their antimicrobial activity using the disc diffusion assay as a screening method against Staphylococus sp, Bacillus sp, Trichoderma reesei and Aspergillus niger. We have also investigated the anti-apoptotic test on Saccharomyces cerevisiae over-expressing the p53 tumor suppressor gene [31]. No positive results were obtained but the assayed oils caused toxicity on this yeast. Because of the great number of constituents, essential oils seem to have no specific cellular targets [32].

Essential oils of flowers showed antifungal activity against Trichoderma reesei with inhibition zone diameter in range of 4 $\mathrm{mm}$ for the 2012-extract to $5 \mathrm{~mm}$ in 2013 at $15 \mathrm{mg} / \mathrm{mL}$, as well as on Bacillus sp with an inhibition zone in the range of 2 $\mathrm{mm}$ for both extracts of 2012 and 2013. Interestingly, the essential oils extracted from plants w/o flowers showed highest antimicrobial activity: Antifungal activity against Trichoderma reesei was pronounced at a dose of $10 \mathrm{mg} / \mathrm{mL}$ for both two years 2012 and 2013. Similarly, stronger positive results were obtained with either Bacillus sp or Staphylococcus aureus at the dose of $10 \mathrm{mg} / \mathrm{mL}$.

Table 4. Concentrations and inhibitory zones of obtained essential oils.

\begin{tabular}{|c|c|c|c|c|c|c|c|c|}
\hline \multirow{3}{*}{ Microorganisms } & \multicolumn{4}{|c|}{ Flowers Essential oil } & \multicolumn{4}{|c|}{ Plant w/o flowers essential oil } \\
\hline & \multicolumn{2}{|c|}{2012} & \multicolumn{2}{|c|}{2013} & \multicolumn{2}{|c|}{2012} & \multicolumn{2}{|c|}{2013} \\
\hline & $\mathrm{a}_{10}$ & 15 & 10 & 15 & 10 & 15 & 10 & $15 m$ \\
\hline Staphylococcus sp & - & nt & & nt & 6 & $\mathrm{nt}$ & 4 & $\mathrm{nt}$ \\
\hline Bacillus sp & $b_{2}$ & $\mathrm{nt}$ & 2 & nt & 5 & $\mathrm{nt}$ & 4 & nt \\
\hline Trichoderma reesei & - & 5 & & 4 & 4 & 5 & 2 & 7 \\
\hline
\end{tabular}

${ }^{\text {a }}$ concentrations in $\mathrm{mg} / \mathrm{mL}$.

${ }^{\mathrm{b}}$ inhibition diameter in $\mathrm{mm}$. $\mathrm{nt}$, not tested.

In conclusion, these observations show that the studied essential oils posses a low or relatively moderate antimicrobial activity. Tests performed show that essential oils from plant w/o flowers are more actives than those obtained directly from flowers. Nevertheless, more studies are required to elucidate the structure of the unidentified components in the oils and evaluate more biological activities of purified and concentrated components.

\section{REFERENCES}

[1] Angiosperm phylogeny Website. Version 8, [Web Page] June 2007; Available from www.mobot.org/MOBOT/research/APweb/ consulted 27/03/2008.

[2] B, Nordenstam. 1977. In the Biology and Chemistry of the Compositae. Academic press. London. 815.

[3] R, Tundis., M, R, Loizzo., G, A, Statti., B, Deguin., R, Amissah., P, J, Houghton., and F, Menichini. 2005. Chemical Composition of and Inhibition of Angiotensin-Converting Enzyme by Senecio samnitum Huet. Pharm. Biol. 43(7), 605608.

[4] F, Bohlmann., C, Zdero., J, Jakupovic., M, Grenz., V, Castro., R, M, King., H, Robinson., And L, P, D, Vincent. 1986. Further pyrrolizidine alkaloids and furoeremophilanes from Senecio species. Phytochemistry. 25, 1151-1159.

[5] J, G, Urones., P, B, Barcala., I, S, Marcos., R, F, Moro., M, Esteban Lo`pez., and F, Rodriguez. 1988. Pyrrolizidine Alkaloids from Senecio gallicus and Senecio adonifolius. Phytochemistry. 27, 1507-1510.

[6] A, L, Pe'rez., P, Vidales., J, Cardenas., And R, DeVivar. 1991. Eremophilanolides from Senecio toluccanus var. Modestus. Phytochemistry. 30, 905-908.

[7] T, Hartmann., and L, Witte. 1995. Chemistry, Biology and Chemecology of pyrrolizidine alkaloids: Chemical and Biological perspective. Edition: Pelletier SW. Permagon. Oxford 9, 155-233.

[8] E, F, Rose. 1972. Senecio species: Toxic plants used as food and medicine in the Transkei. S. Afr. Med. 46, 10391043.

[9] J, Bautista Peres., G, Stubing., and R, Figuerola. 1991. Guia de las Plantas Medicinales de la Communidad Valenciana Valencia. Las Provincial.

[10] C, Pe'rez., A, M, Agnese., and J, L, Cabrera. 1999. The essential oil of Senecio graveolens (Compositae): Chemical composition and antimicrobial activity tests. J. Ethnopharmacol. 66, 91-96.

[11] L, A, Loyala., S, Pedreros., and G, Morales. 1985. P-Hydroxyaceto-phenone derivatives from Senecio graveolens. Phytochemistry. 24, 1600-1602.

[12] Z, Noumi., S, Ouled Dhaou., S, Derbel., and M, Chaieb. 2010. The status of Asteraceae in the arid and Saharian flora of North African region: case of Tunisia. Pak. J. Bot. 42(3), 1417-1422. 
[13] M, Mitsuo., H, Nobutaka., and Kameoka. 1979. Koen Yoshishu-Koryo, Terpen oyobi Seiyu Kagaku ni Kans-uru Toronkai, 23rd. 51 Symposium on the chemistry of terpenes, Essential oils and aromatics.

[14] B, Van Dooren., R, Bos., and D, H, E, Tattje. 1981. Composition of essential oils of some Senecio species. Planta Med. 42, 385-389.

[15] H, L, De Pooter., L, F, De Buyck., N, M, Schamp., E, A, Aboutabl., A, De DE Bruyn., and S, Z, Husain. 1986. The volatile fraction of senecio glaucus sbsp.coronopifolius. Flavour Frag. J. 1, 159-163.

[16] N, Mangi., S, N, Grag., S, K, Agarwal., and C, S, Mathela. 1995. The occurrence of $\beta$-thujone and a new p-menthane derivative in Senecio chrysanthenemoides leaf oil. J. Ess. Oil Res. 7, 511-514.

[17] M, H, Grace., and A, M, Khattab . 1998. Chemical constituents and molluscicidal activity of Senecio cineraria D. C. Egypt. J. Pharm. Sci. 39, 253-266.

[18] A, M, El-Shazly. 1999. Essential Oil composition of Senecio desfontainei Druce (Compositae) Zagazig. J. Pharm. Sci. $8,1-8$.

[19] C, Floret., and R, Pontanier. 1982. L'aridité en Tunisie présaharienne, Travaux et documents de l'orstom. 540.

[20] R, M, A, Mansour., and N, A, M, Saleh. 1981. Flavonoids of three local Senecio species, Photochemistry. 20(5), 11801181.

[21] J, G, Urones., P, B, Barcala., T, De Pascual., I, S, Marcos., R, F, Moro., B, Pilar Basabe., and C, Jose Sexmero. 1987. Acetophenones and terpenoids from Senecio gallicus. Phytochemistry. 26(4), 1113-1115.

[22] E, Le Floch. 1983. Contribution à une étude ethnobotanique de la flore tunisienne. Publié par le ministère de l'enseignement supérieur et de la recherche scientifique. Tunis. Tunisie.

[23] M, Boukris., and M, Chaieb. 1998. Flore succincte et illustrée des zones arides et sahariennes. Edition Or du Temps. Tunisie.

[24] A, Akrout., H, El Jani., T, Zammouri., H, Mighri., and M, Neffati. 2010. Phytochemical screening and mineral contents of annual plants growing wild in the southern of Tunisia. J. Phytol. 2(1), 034-040.

[25] E, Kovats. 1965. Gas chromatographic characterization of organic substances in the retention index syste. Adv. Chromatogr. 1, 229-247.

[26] M, Mohammadhosseini., A, Pazoki., H, A, Zamani., H, Akhlaghi., and M, Nekoei. 2010. Chemical Composition of the Essential Oil from Aerial Parts of Senicio gallicus Chaix Growing Wild in Iran. Bear. PI. 13(6), 704-709.

[27] B, M, Lawrence. 1988. Perfum. Flavor. 13(5), 61.

[28] R, Atkinson., S, M, Aschmann., and J, Arey. 1990. Rate constants for the gas-phase reactions of $\mathrm{OH}$ and $\mathrm{NO}$ radicals and $\mathrm{O} 3$ with sabinene and camphene at 296 $\pm 2 \mathrm{~K}$. Atmos. Environ. 24A(10), 2647-2654.

[29] H, Hakola., J, Arey., S, M, Aschmann., and R, Atkinson. 1994. Product formation from the gas-phase reactions of $\mathrm{OH}$ radicals and $\mathrm{O} 3$ with a series of monoterpenes. J. Atmos. Chem. 18, 75-102.

[30] J, Yu., D, R, Cocker III., R, J, Griffin., R, C, Flagan., and J, H, Seinfeld. 1999. Gas-phase ozone oxidation of monoterpenes: gaseous and particulate products. J. Atmos. Chem. 34, 207-258.

[31] I, Yacoubi-Hadj Amor., K, Smaoui., H, Belguith., L, Djemal., M, Dardouri., R, Mokdad Gargouri., and A, Gargouri . 2009. Selection of cell death deficient P53 mutants in Saccharomyces cerevisia. Yeast. 26(8), 441-450.

[32] C, F, Carson., B, J, Mee., and T, V, Riley. 2002. Mechanism of action of Melaleuca alternifolia (tea tree) oil on Staphylococcus aureus determined by time-kill, lysis, leakage and salt tolerance assays and electron microscopy. Antimicrob. Agents Chemother. 46, 1914-1920.

\section{Author' biography}

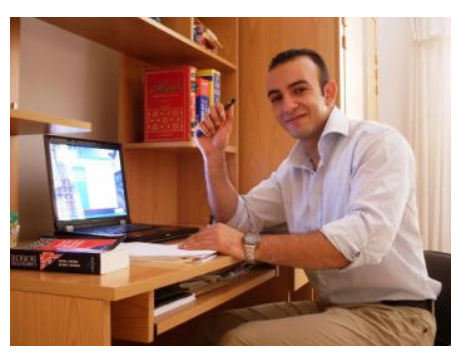

Mohamed Mihoubi was born in Sakiet Sidi Youssef (Tunisia) on Sunday 20 March 1988. He is the youngest of four children, what some might call the "baby" of the family.There he cultivated his love of traveling, discovering and adventure through the clubs and associations that he had joined and also through the trips that he had made. After 18 years and after finishing the high school and obtaining the baccalaureate degree he moved to the south of Tunisia in the city of Sfax where his home base now resides. On 2007 he attended the University of Sfax, precisely the faculty of science of Sfax, that satisfied his ambitions. There, he joined an academic training on the field of general chemistry. in 2010, he received two bachelor degrees in respectively general chemistry and physics. He was a very active student, when he is not in school and when he is not preoccupied by other local activities, Mohamed enjoys spending his time writing (Poetry, Sciences, Articles) as it is a dream of him to have his writings published. After that he had continued his studies in the field of organic chemistry to 
get graduated on July 16, 2012 the master degree with honors under the supervision of Professor Raoudha Jarraya. After all these years of studies Mohamed decided to join the Tunisian national guard (militarian organisation) with the experience that he had made and with his love toward this domain, January 7, 2013 he was graded as a lieutenant and his dream became a reality, he was the youngest officer of his promotion. But since the research interests him more than any other domain he decided to quit the work and back again to the laboratory. On his return, conditions were encouraging. In fact he started a 6 months internship in the laboratory of synthesis of heterocyclic compounds directed Professor Giovanni Grassi under the supervision of professor Anna Piperno at the faculty of sciences of Messina, he used to synthesize molecules belonging to the family of alkaloids and possessing interresting biological activities wich is his Phd topic.

Mohamed speaks fluently arabic, french and english and in addition deutch and Italian. He visited a lot of countries such as (Egypt, Algeria, Libya, France, Belgium and Italy).

$\mathrm{He}$ is currently a junior researcher at the "Laboratoire de Chimie des Substances Naturelles" in the faculty of sciences of sfax, directed by professor Ridha Ben Salem, he is making researches on chemistry of plants and natural products in order to obtain his doctorate and achieve his new dream.

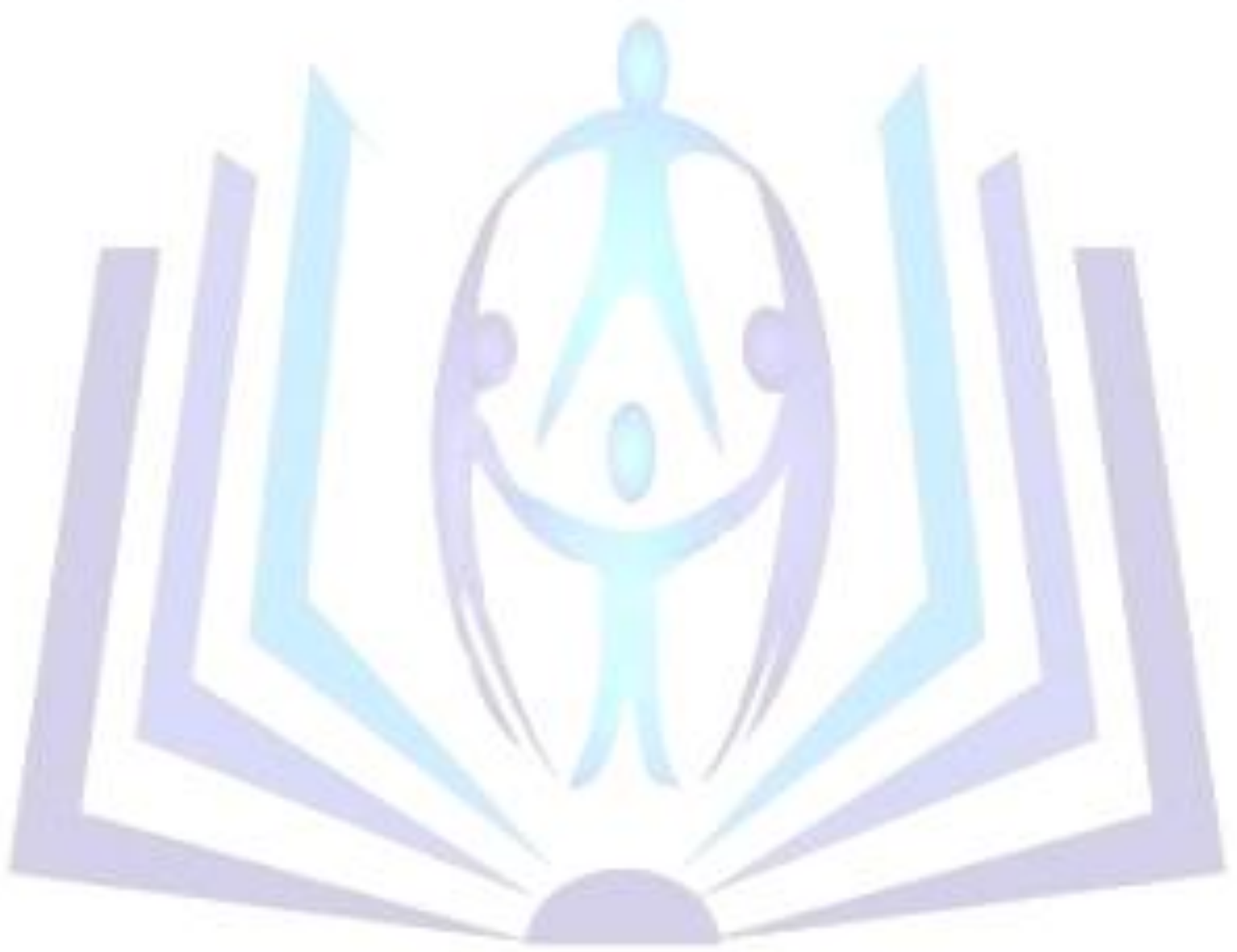

